\title{
PUBLIC-PRIVATE PARTNERSHIPS AND SCHOOLING OUTCOMES ACROSS COUNTRIES
}

\author{
LUDGER WOESSMANN
}

CESIFO WORKING PAPER NO. 1662

CATEgory 1: Public FinAnCE

FEBRUARY 2006

An electronic version of the paper may be downloaded

- from the SSRN website:

wWw.SSRN.com

- from the CESifo website:

www.CESifo-group.de 


\title{
PUBliC-PRIVATE PARTNERSHIPS AND SCHOOLING OUTCOMES ACROSS COUNTRIES
}

\begin{abstract}
The paper provides a comparative analysis of the association between student achievement and public-private partnerships (PPPs) in schooling across countries. Student-level data from the PISA international achievement test provides information on the public-private character of both operation and funding of each tested school. Across countries, public operation is associated with lower student outcomes, but public funding with better student outcomes. Thus, systems of PPPs that combine private operation with public funding do best among all possible operation-funding combinations, while PPPs that combine public operation with private funding do worst. The advantage of private operation is particularly strong in countries with large shares of public funding.
\end{abstract}

JEL Code: I20, L33, H42, H52.

\author{
Ludger Woessmann \\ Ifo Institute for Economic Research \\ at the University of Munich and CESifo \\ Poschingerstr. 5 \\ 81679 Munich \\ Germany \\ woessmann@ifo.de
}

This version: January 13, 2006

Paper prepared for the PEPG - World Bank conference "Mobilizing the Private Sector for Public Education", Kennedy School of Government, Harvard University, October 2005. I would like to thank the participants of the conference, in particular the two conference organizers Raji Chakrabarti and Paul Peterson and my discussant Marty West, for very useful comments and discussions. A first draft of this paper was circulated under the title "PublicPrivate Partnerships in Schooling: Cross-Country Evidence on their Effectiveness in Providing Cognitive Skills" as Harvard University's Program on Education Policy and Governance Research Paper PEPG 05-09. 


\section{Introduction}

The issue of public-private partnership (PPP) is a much-debated topic, and increasingly so in the education sector (for examples, cf. Human Development Network 2001; Peterson 2003). However, given that PPPs are mostly either project-based endeavors or systemic features of whole education systems, evidence usually comes only in the case-study form (cf., e.g., World Bank 2004, chapter 7; Patrinos 2000, 2002). This paper, by contrast, uses the opportunities of internationally comparable data to provide cross-country evidence on the association between student achievement and PPPs across different countries. The PISA international student achievement study tested students' basic skills in math, reading and science in an internationally comparable way. The PISA micro database is unique among recent international tests in containing information for each tested school both about whether it is publicly or privately operated and about what share of its funding comes from public and private sources. These data provide the opportunity of presenting "big picture" cross-country evidence on PPPs in schooling.

Such an international perspective carries two particular advantages relative to analyses within a country. First, comparisons across countries allow for the recognition of systemic effects, in that the existence of private schools may affect the behavior and performance of nearby public schools. If public schools behave differently because there are private schools nearby, then there may be effects of private involvement even though the performance between individual private and public schools may not differ. Cross-country evidence can detect such systemic effects where both private and public schools may perform at a higher level because of the existence of private competition. The second advantage of cross-country evidence is that it allows analyzing possible differences in the effects of PPPs when they exist in different situations.

In basically all countries, the ultimate responsibility and supervision of the school system remain with the state - whether the system makes use of PPPs or not. But beneath this state supervision, both the operation and the funding of schools may show differing shares of public vs. private involvement. If we think of school operation and school funding as the two broad tasks under consideration, and if we understand PPPs as any collaboration between public and private entities, then conceptually there are two specific ways in which PPPs can exist in the school system. In the first case, schools are operated (managed) by a public entity, but draw heavily on private funding - e.g., parents have to pay tuition fees. In the second 
case, schools are operated by a private entity - be it a business, the church or else - but get most of their funding from a public entity - be it through base funding or vouchers.

As Figure 1 shows, both forms of PPPs exist in a system-wide manner. ${ }^{1}$ In the first type of PPP, prevalent in the systems in the top left quadrant of Figure 1, the majority of schools are operated by private entities, but all schools receive the vast majority of their funding from public sources. This combination is given in the Netherlands, Belgium, Ireland and, to a lesser degree, in Denmark. The second type of system-wide PPP combines a high share of public operation with a relatively low share of public funding. This combination of private financing of publicly managed schools, depicted in the bottom right quadrant of Figure 1, exists particularly in Mexico, but to a lesser extent, it can also be observed in Italy, New Zealand, Brazil and Greece.

Figure 1 depicts two more groups of countries that do not constitute partnerships between the public and the private, but are rather mostly private or purely public. The systems in the bottom left quadrant combine relatively low shares of public operation and public funding. This is true in Korea, where about half of both operation and funding is private, and to a lesser extent in Japan, France and Spain. Finally, in the systems in the top right quadrant, the vast majority of schools is both publicly operated and publicly funded. This is particularly true in Norway, Iceland, Finland, Sweden, Latvia and Germany. But actually, most countries have the vast majority of their schools both publicly operated and publicly funded. Both in terms of the share of publicly operated schools and in terms of the average share of public funding of schools, 20 out of 29 countries have more than $87 \%$ public involvement.

This paper will analyze the efficacy of the four types of systems - private operation with public funding, public operation with private funding, substantial private operation and funding, and purely public operation and funding - in terms of student outcomes. While it will detect substantial performance differences between the different forms of systems, a quick glance at Figure 1 already reveals that a simple division between public operation and funding on the one side and private operation and funding on the other side does not seem to be fundamentally decisive for student performance. For example, two well-known top performers in PISA, Finland and Korea, characterize the opposite systems of sole public responsibility (100\% public funding and 97\% publicly operated schools in Finland) and large

\footnotetext{
1 Details on the data underlying Figure 1 will be provided in Section 2.2 below. Note that the specific subdivision into the four quadrants in the Figure is arbitrary, chosen in a way so that each quadrant has at least four countries, and is undertaken for purposes of visualization only.
} 
Figure 1: Public Funding and Public Operation of Schools

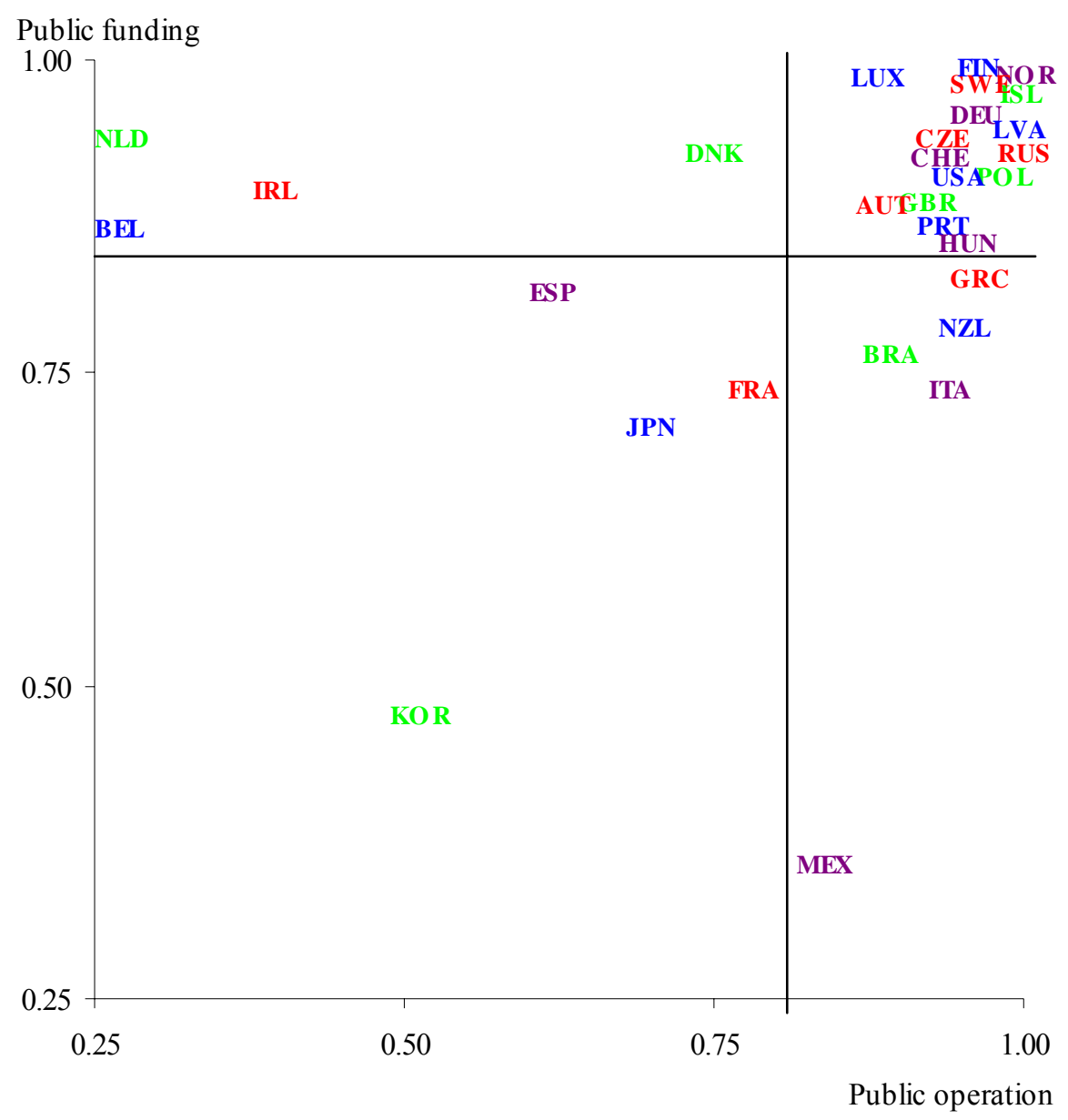

Notes: Average share of public funding and share of publicly operated schools in the country, respectively.

The acronyms stand for: AUT: Austria, BEL: Belgium, BRA: Brazil, CZE: Switzerland, CHE: Czech Republic, DEU: Germany, DEN: Denmark, ESP: Spain, FIN: Finland, FRA: France, GBR: United Kingdom, GRC: Greece, HUN: Hungary, IRL: Ireland, ICE: Iceland, ITA: Italy, JPN: Japan, KOR: Korea, LUX: Luxembourg, LVA: Latvia, MEX: Mexico, NLD: Netherlands, NOR: Norway, NZL: New Zealand, POL: Poland, PRT: Portugal, RUS: Russian Federation, SWE: Sweden, USA: United States.

Source: Own calculations based on PISA micro database. 
private involvement (51\% private funding and 49\% privately operated schools in Korea). But we will see that the more intricate combination of public and private involvement in the two forms of PPPs seems to have important consequences for students' educational performance.

While there are the discussed advantages of cross-country evidence, it also has shortcomings. Despite the extensive information on family and school background that allows accounting for other observable influence factors, thereby allowing comparing students who are equal in terms of other observable characteristics, the international student achievement test still provides observational data. In these data, private involvement is not randomly divided between a treatment group that has private involvement and a control group that does not have private involvement. Therefore, in contrast to randomized experimental evidence, the evidence presented in this paper has to be interpreted cautiously in terms of descriptive conditional correlations, which do not necessarily allow for causal inferences because they may also reflect effects of other, unobservable characteristics. Still, the multivariate analysis goes substantially beyond bivariate correlations in terms of detecting underlying relationships by disentangling these relationships from other observable influences at the student level. Furthermore, as will be discussed in Section 4.1, theory has some guidance as to which direction some of the main sources of potentially remaining bias in the presented "higherlevel descriptives" point, which can help in the interpretation of results. But ultimately, remaining bias due to selection on unobservables cannot be ruled out.

While the paper goes into the question of effects of different forms of private involvement in some detail, it should also be clarified right from the start what the paper is not about. The topic of the paper is explicitly the effectiveness of PPPs in providing cognitive skills for students. Therefore, it does not deal with questions of efficiency (for which relative costs would have to be taken into account), nor with questions of equity of school systems with differing private involvement, nor with questions of the provision of non-cognitive skills. While it goes without saying that all these issues are of tremendous importance, they go beyond the scope of this paper.

\section{Public and Private Involvement in Schooling around the World}

Before we describe the models and econometric evidence, this section provides some background on the international data as well as some more thorough descriptive patterns of public and private involvement in schooling around the world. 


\subsection{The PISA Database}

The database of the Programme for International Student Assessment (PISA) distinguishes itself from previous international tests by providing data both on whether individual schools are publicly or privately operated and on what shares of schools' funding stems from public and private sources. PISA is an international student achievement test of representative random samples of 15-year-old students conducted in 2000 by the Organisation for Economic Co-Operation and Development (OECD). The study tested student performance in math, reading and science in 32 developed and emerging countries, 29 of which can be used in this paper. ${ }^{2}$ The OECD ensured a consistent and coherent study design and as much comparability as possible among the participating countries. ${ }^{3}$

The PISA 2000 study had a special focus on the reading literacy of students, with a sample size of the database used in this paper of 130,242 students. The sample sizes in the other two subjects are 72,493 students in math and 72,388 students in science. In this paper, the main focus will be on reading performance - because of the larger sample size - and on math performance, which is generally viewed as being most readily comparable across countries. Also, math performance has often been found to be most strongly related to productivity (e.g., Bishop 1992). The specific student-level database used in this paper was constructed by Fuchs and Wößmann (2004), who provide more detailed information and notes on the specific database. They combine the test results with rich background information on students and schools from PISA background questionnaires answered by the specific students and heads of schools tested in PISA and with additional country-level data. ${ }^{4}$

As a general background on the data, Table 1 provides descriptive statistics for each country on the level and variation of test performance in the three subjects. The test results were scaled on a score with an OECD mean of 500 points and an OECD standard deviation of 100 points. In all data descriptions and analyses presented in this paper, only students in schools that had both data on private vs. public operation and on the share of private vs.

2 Among the PISA participants, Australia and Canada did not provide data on the public vs. private operation of schools. Liechtenstein was not included in the analysis because it features only 11 schools (with 314 students), 2 of which are private, and because it lacks several internationally comparable country-level data. Data for the Netherlands are provided, although there is a caveat in that the response rate in the Netherlands was relatively low.

3 Adams and Wu (2002), OECD (2001) and the PISA webpage at www.pisa.oecd.org provide detailed information on the PISA study.

4 Fuchs and Wößmann (2004) also provide imputed data for missing observations, which are used in this paper with the exception of the data on private vs. public operation and funding, for which only original data is used. 
Table 1: Test Performance and Sample Size

\begin{tabular}{|c|c|c|c|c|c|c|c|c|c|c|}
\hline & \multicolumn{2}{|c|}{ Math } & \multicolumn{2}{|c|}{ Reading } & \multicolumn{2}{|c|}{ Science } & \multirow{2}{*}{\begin{tabular}{|} 
Sample \\
size \\
(students) \\
$(\mathrm{G})$ \\
\end{tabular}} & \multirow{2}{*}{$\begin{array}{c}\text { Sample } \\
\text { size } \\
\text { (schools) } \\
(\mathrm{H}) \\
\end{array}$} & \multirow{2}{*}{$\begin{array}{c}\text { Number of } \\
\text { privately operated } \\
\text { schools in sample } \\
\text { (I) } \\
\end{array}$} & \multirow{2}{*}{$\begin{array}{c}\text { Missing } \\
\text { in original } \\
\text { sample }^{\mathrm{a}} \\
(\mathrm{J}) \\
\end{array}$} \\
\hline & $\begin{array}{l}\text { Score } \\
\text { (A) } \\
\end{array}$ & $\begin{array}{l}\text { SD } \\
\text { (B) } \\
\end{array}$ & $\begin{array}{l}\text { Score } \\
\text { (C) } \\
\end{array}$ & $\begin{array}{l}\text { SD } \\
\text { (D) } \\
\end{array}$ & $\begin{array}{c}\text { Score } \\
(\mathrm{E}) \\
\end{array}$ & $\begin{array}{l}\text { SD } \\
(\mathrm{F}) \\
\end{array}$ & & & & \\
\hline AUT & 515 & 92 & 507 & 93 & 519 & 91 & 4,501 & 203 & 20 & 5.1 \\
\hline BEL & 520 & 106 & 507 & 107 & 496 & 111 & 6,345 & 203 & 149 & 4.9 \\
\hline BRA & 334 & 97 & 396 & 86 & 375 & 90 & 3,956 & 256 & 27 & 19.1 \\
\hline $\mathrm{CHE}$ & 529 & 100 & 494 & 102 & 496 & 100 & 5,830 & 269 & 26 & 4.4 \\
\hline CZE & 498 & 96 & 492 & 96 & 511 & 94 & 5,343 & 228 & 23 & 0.4 \\
\hline DEU & 490 & 103 & 484 & 111 & 487 & 102 & 4,442 & 192 & 8 & 12.4 \\
\hline DNK & 514 & 87 & 497 & 98 & 481 & 103 & 4,009 & 208 & 51 & 5.3 \\
\hline ESP & 476 & 91 & 493 & 85 & 491 & 95 & 5,818 & 174 & 65 & 6.4 \\
\hline FIN & 536 & 80 & 546 & 89 & 538 & 86 & 4,864 & 155 & 6 & 0.0 \\
\hline FRA & 517 & 89 & 505 & 92 & 500 & 102 & 4,080 & 153 & 36 & 12.7 \\
\hline GBR & 529 & 92 & 523 & 100 & 532 & 98 & 8,676 & 337 & 16 & 7.1 \\
\hline GRC & 447 & 108 & 474 & 97 & 461 & 97 & 4,305 & 144 & 5 & 7.9 \\
\hline HUN & 488 & 98 & 480 & 94 & 496 & 103 & 4,766 & 183 & 8 & 2.5 \\
\hline IRL & 503 & 84 & 527 & 94 & 513 & 92 & 3,793 & 137 & 83 & 1.6 \\
\hline ISL & 514 & 85 & 507 & 92 & 496 & 88 & 3,236 & 125 & 2 & 4.0 \\
\hline ITA & 457 & 90 & 487 & 91 & 478 & 98 & 4,704 & 161 & 9 & 5.6 \\
\hline JPN & 557 & 87 & 522 & 86 & 550 & 90 & 5,217 & 134 & 39 & 0.7 \\
\hline KOR & 547 & 84 & 525 & 70 & 552 & 81 & 4,676 & 137 & 64 & 6.1 \\
\hline LUX & 446 & 93 & 441 & 100 & 443 & 96 & 3,251 & 22 & 3 & 7.9 \\
\hline LVA & 463 & 103 & 458 & 102 & 460 & 98 & 3,038 & 123 & 1 & 22.0 \\
\hline MEX & 387 & 83 & 422 & 86 & 422 & 77 & 3,894 & 156 & 26 & 15.3 \\
\hline NLD & 556 & 89 & 530 & 91 & 527 & 96 & 2,246 & 89 & 66 & 10.3 \\
\hline NOR & 499 & 92 & 505 & 104 & 500 & 96 & 3,972 & 165 & 3 & 4.2 \\
\hline NZL & 537 & 99 & 529 & 108 & 528 & 101 & 3,456 & 144 & 7 & 5.8 \\
\hline POL & 470 & 103 & 479 & 100 & 483 & 97 & 3,586 & 125 & 5 & 1.9 \\
\hline PRT & 454 & 91 & 470 & 97 & 459 & 89 & 4,554 & 148 & 11 & 0.7 \\
\hline RUS & 478 & 104 & 462 & 92 & 460 & 99 & 6,566 & 242 & 0 & 2.0 \\
\hline SWE & 510 & 93 & 516 & 92 & 512 & 93 & 4,416 & 154 & 6 & 0.0 \\
\hline USA & 493 & 98 & 504 & 105 & 499 & 101 & 2,947 & 116 & 6 & 23.4 \\
\hline Mean & 492 & 94 & 492 & 95 & 492 & 95 & $130,487^{b}$ & $4,883^{b}$ & $771^{b}$ & 6.6 \\
\hline
\end{tabular}

Notes: See notes to Figure 1 for a list of country acronyms. ${ }^{\text {a }}$ Percentage of observations without information on public operation or funding. These observations are not counted in the columns on sample size. ${ }^{\mathrm{b}}$ Sum.

Source: Own calculations based on PISA micro database. 
public funding were included. The sample size stands at an average of 4,500 students in 168 schools per country.

\subsection{Differing Patterns of Public and Private Funding and Operation}

In the PISA database, data on public vs. private operation of schools comes in the form of a dummy that classifies each school as either public or private. In the school background questionnaire, a public school was defined as "a school managed directly or indirectly by a public education authority, government agency, or governing board appointed by government or elected by public franchise." A private school, by contrast, was defined as "a school managed directly or indirectly by a non-government organization; e.g., a church, trade union, businesses, other private institutions."

Data on public vs. private funding of schools is recorded as the respective share of total funding coming from public and private sources. Heads of school were asked, "About what percentage of your total funding for a typical school year comes from the following sources?", where the answer categories were "Government (includes departments, local, regional, state and national)", "Student fees or school charges paid by parents", "Benefactors, donations, bequests, sponsorships, parent fund raising" and "Other". For the purposes of this paper, only the first category was classified as public funding, and the remaining sources as private funding.

Descriptive statistics on the share of publicly operated schools and the average share of public funding in each country, already visualized in Figure 1, are provided in Table 2. On average across the 29 countries, $83 \%$ of schools are publicly operated, and the remaining $17 \%$ are managed by a private entity. But the share of publicly operated schools varies substantially across countries, with Belgium (25\%) and the Netherlands (26\%) at the bottom end and Russia (100\%), Latvia (99\%) and Iceland (99\%) at the top end. The average share of public funding of schools across the countries is $87 \%$, with Mexico (37\%) and Korea (49\%) at the lower end and Luxembourg, Sweden, Finland, Norway and Iceland all with a public share above $99 \%$.

From the perspective of PPPs, it is particularly interesting to note that the shares of public involvement in operation and funding can differ substantially within a country (column (M) in Table 2). At the one extreme, the public share is substantially larger in funding than in operation in the Netherlands (difference of 69 percentage points), Belgium (63) and Ireland 
Table 2: International Differences in Public Funding and Public Operation of Schools

\begin{tabular}{|c|c|c|c|c|c|c|}
\hline & $\begin{array}{c}\text { Average } \\
\text { share of } \\
\text { public funding } \\
(\mathrm{K}) \\
\end{array}$ & $\begin{array}{c}\text { Share of } \\
\text { publicly operated } \\
\text { schools } \\
\text { (L) } \\
\end{array}$ & $\begin{array}{c}\text { Difference } \\
(\mathrm{M}) \\
\end{array}$ & $\begin{array}{l}\text { Average share of public } \\
\text { funding in publicly } \\
\text { operated schools } \\
(\mathrm{N})\end{array}$ & $\begin{array}{l}\text { Average share of public } \\
\text { funding in privately } \\
\text { operated schools } \\
(\mathrm{O}) \\
\end{array}$ & $\begin{array}{c}\text { Difference } \\
(\mathrm{P}) \\
\end{array}$ \\
\hline AUT & 90.4 & 88.8 & 1.6 & 96.2 & 44.2 & 52.1 \\
\hline BEL & 87.5 & 24.6 & 63.0 & 95.1 & 85.0 & 10.1 \\
\hline BRA & 78.0 & 89.4 & -11.4 & 87.3 & 0.0 & 87.2 \\
\hline $\mathrm{CHE}$ & 93.8 & 93.5 & 0.3 & 98.5 & 25.5 & 73.0 \\
\hline CZE & 94.9 & 93.9 & 1.0 & 96.2 & 74.5 & 21.7 \\
\hline DEU & 97.3 & 95.9 & 1.4 & 98.2 & 77.1 & 21.1 \\
\hline DNK & 94.3 & 75.5 & 18.8 & 99.9 & 76.9 & 23.0 \\
\hline ESP & 82.9 & 61.9 & 20.9 & 95.3 & 62.8 & 32.5 \\
\hline FIN & 99.8 & 97.2 & 2.6 & 99.9 & 98.3 & 1.5 \\
\hline FRA & 75.5 & 77.8 & -2.4 & 77.3 & 69.1 & 8.2 \\
\hline GBR & 89.8 & 90.8 & -1.0 & 98.7 & 2.2 & 96.4 \\
\hline GRC & 83.7 & 95.8 & -12.0 & 87.4 & 0.0 & 87.4 \\
\hline HUN & 87.4 & 95.3 & -7.8 & 87.9 & 78.3 & 9.5 \\
\hline IRL & 91.1 & 39.5 & 51.6 & 98.0 & 86.6 & 11.4 \\
\hline ISL & 99.4 & 99.2 & 0.2 & 99.9 & 40.4 & 59.5 \\
\hline ITA & 75.2 & 94.2 & -19.0 & 79.2 & 10.1 & 69.1 \\
\hline JPN & 72.5 & 69.6 & 2.9 & 88.4 & 36.0 & 52.4 \\
\hline KOR & 49.1 & 50.6 & -1.5 & 54.9 & 43.3 & 11.6 \\
\hline LUX & 100.0 & 87.9 & 12.1 & 100.0 & 100.0 & 0.0 \\
\hline LVA & 95.6 & 99.2 & -3.6 & 95.7 & 89.0 & 6.7 \\
\hline MEX & 36.8 & 84.5 & -47.6 & 43.6 & 0.0 & 43.6 \\
\hline NLD & 94.7 & 26.0 & 68.7 & 94.7 & 94.7 & 0.0 \\
\hline NOR & 99.5 & 98.5 & 1.0 & 99.8 & 82.3 & 17.5 \\
\hline NZL & 80.2 & 95.1 & -14.9 & 83.4 & 18.4 & 65.0 \\
\hline POL & 92.2 & 97.1 & -4.9 & 94.4 & 18.1 & 76.4 \\
\hline PRT & 87.9 & 92.7 & -4.8 & 88.5 & 80.1 & 8.4 \\
\hline RUS & 93.5 & 100.0 & -6.5 & 93.5 & - & - \\
\hline SWE & 99.9 & 96.6 & 3.3 & 99.9 & 99.3 & 0.6 \\
\hline USA & 91.6 & 94.6 & -2.9 & 95.6 & 22.1 & 73.6 \\
\hline Mean & 86.9 & 83.0 & 3.9 & 91.2 & 65.9 & 25.4 \\
\hline
\end{tabular}

Notes: In percent. See notes to Figure 1 for a list of country acronyms.

Source: Own calculations based on PISA micro database. 
(52). At the other extreme, the public share can also be substantially larger in operation than in funding, as for example in Mexico (difference of 48 percentage points) and Italy (19).

It is also revealing to look at the relative shares of public funding in publicly vs. privately operated schools in each country (columns $(\mathrm{N})$ and $(\mathrm{O})$ in Table 2). Thus, while in most countries publicly operated schools receive nearly all of their funding from public sources, $56 \%$ of the funding of publicly operated schools in Mexico stems from private sources, and $45 \%$ in Korea. On average across all countries, the share of public funding in publicly operated schools (at 91\%) is 25 percentage points higher than in privately operated schools (at $66 \%$ ). The share of public funding in privately operated schools differs particularly strongly across countries, with the privately operated schools tested in Brazil, Greece and Mexico receiving no funding at all from public sources (and those in the United Kingdom only 2\%), while privately operated schools in the Netherlands, Finland, Luxembourg and Sweden receive more than $95 \%$ of their funding from public sources.

Even more striking is the difference in public funding that publicly and privately operated schools in a country receive (column (P) in Table 2). At the one extreme, the share of public funding in UK public schools is 96 percentage points higher than in UK private schools. This difference is also quite large in other countries, such as Greece ( 87 percentage points), Brazil (87), Poland (76), the United States (74) and Switzerland (73). At the other extreme, there is no difference at all in the share of public funding between publicly and privately operated schools in the Netherlands and Luxembourg, and the differences are also very small in Sweden (0.6 percentage points) and Finland (1.5).

\section{Why Should the Public-Private Division Matter?}

Do these cross-country differences in public vs. private involvement in the operation and funding of schools matter for student achievement? From a theoretical point of view, positive and negative aspects of both operation and funding of schools by the state vs. the private sector have been advanced in the literature. The main case usually made in terms of the operation of schools is that private operation is more efficient than public operation because market forces create incentives for cost containment and performance-conducive qualitative innovation in private school management (e.g., Chubb and Moe 1990; Hanushek et al. 1994; Shleifer 1998; Bishop and Wößmann 2004). In accordance with this reasoning, empirical evidence tends to find that performance in privately managed schools is superior to 
performance in publicly managed schools. ${ }^{5}$ Some of the empirical contributions also show that the existence of private schools improves the performance of nearby public schools that face their competition, an issue that complicates the empirical identification of the effects of private school operation and that we will come back to below.

The case in favor of public provision of schools is less clear, if we separate it from the conceptually different case of public vs. private funding, in particular because the government could always write specific contracts with private providers to ensure that certain requirements are observed (cf. Shleifer 1998). However, one point sometimes advanced in favor of public provision is that only direct public provision of schooling could yield an inculcation of students with ideological and cultural goals and beliefs pursued by the government, a task that might not be easily contracted out to the private sector (e.g., Gradstein and Justman 2002; Pritchett 2003). Ideological inculcation may be an issue hard to pin down empirically, and it is certainly beyond the scope of a paper focusing on cognitive skills. But in a similar vein, direct public school operation might allow a closer monitoring of implemented curricula - although the incentives for monitoring may again be stronger in the private sector.

In terms of the relative merits of public and private funding (as opposed to operation) of schools, it is sometimes argued that private or parents-based funding can increase accountability and provide incentives for efficient behavior from the demand side (cf. Jimenez and Paqueo 1996; Chubb and Moe 1990). It is not obvious, though, to what extent this benefit of private involvement would go beyond the benefit of private provision and the choice that parents can make between different private providers, which would already induce performance-conducive incentives from the demand side.

This latter point can even be turned into the opposite case favoring public funding, if combined with the idea that some families may be too poor to choose privately operated schools if they have to be funded privately. As long as there are credit constraints that prevent poor families from borrowing against possible future income gains of their children due to improved educational performance (cf. Loury 1981; Galor and Zeira 1993; Gradstein et al. 2004), poor families' choices of better schools that require higher private funding will be

5 Important contributions to the empirical literature include Howell et al. (2002), Hoxby (2003a, 2003b) and Neal (1997) for the United States, Bradley and Taylor (2002) and Levacić (2004) for England, Sandström and Bergström (2005) for Sweden, Angrist et al. (2002) for Colombia, Cox and Jimenez (1991) for Colombia and Tanzania, James et al. (1996) and Bedi and Garg (2000) for Indonesia and Mizala and Romaguera (2000), Mizala et al. (2002), Sapelli and Vial (2002), Vegas (2002) and Hsieh and Urquiola (2003) for Chile. 
constrained. Public funding can relax the credit constraints, which can allow greater choice for all families and therefore increase schools' incentives to behave efficiently. The empirical evidence of positive performance effects of (mostly publicly provided) school vouchers to finance the attendance of privately operated schools (see references above) can be viewed as one aspect of this possible positive effect of public funding. ${ }^{6}$

Given the different theoretical arguments as summarized in Table 3, we might expect the public vs. private nature of the operation and funding of schools to have an impact on student achievement. The direction and size of this impact remains an empirical question, though.

\section{The Empirical Models}

This section describes the different specifications of the empirical model of the association between PPPs and student performance analyzed in this paper, and how they may or may not be affected by selection bias.

\subsection{Observables, Unobservables and the Possibility of Selection Bias}

Given the separate arguments for and against public involvement in the operation and funding of schools, assume that the true achievement model includes separate effects of operation and funding and can be represented by:

$$
T_{i}=\alpha+\beta_{1} O_{s}+\beta_{2} F_{s}+B_{i} \beta_{3}+U_{i} \beta_{4}+\varepsilon_{i}
$$

where $T_{i}$ is the achievement test score of student $i, O_{s}$ is a dummy showing whether the student's school $s$ is publicly (as opposed to privately) operated, and $F_{s}$ is the share of the school's funding stemming from public (as opposed to private) sources. $B$ are additional background features that can be observed, like parent's level of education, $U$ are additional features affecting performance that remain unobserved, for example parents' valuation of their children's education, and $\varepsilon_{i}$ is an error term.

What are the consequences of $B$ und $U$ for our estimates of the association between public involvement and student performance? Two observations can help us understand the specific nature of one of the main sources of possible bias in our empirical models. First, given that we look at the effects of operation and funding separately, the arguments on credit constraints

\footnotetext{
6 A lot of the discussion of the relative merits of public vs. private involvement in schooling, in particular on the funding side, also surrounds equity rather than effectiveness outcomes (cf., e.g., Glomm and Ravikumar 1992; Epple and Romano 1998; Nechyba 2000; Ladd 2002). For reasons of scope, in this paper we do not deal with the issue that public funding might serve to redistribute income or to raise opportunities for specific disadvantaged sub-groups of the population, leaving this important issue for future research.
} 
Table 3: Aspects of Public and Private Involvement in School Provision and Funding

Positive aspects of involvement of:

Public sector

Private sector

\begin{tabular}{lcc}
\hline Operation & $\begin{array}{c}\text { Inculcation of beliefs } \\
\text { and cultural values }\end{array}$ & $\begin{array}{c}\text { Incentives for cost containment } \\
\text { and qualitative innovation }\end{array}$ \\
Funding & $\begin{array}{c}\text { Enabling choice for } \\
\text { credit-constrained families }\end{array}$ & Increased accountability \\
\hline
\end{tabular}


discussed in Section 3 above bear on the association between family background and funding, but not on the private vs. public operation of schools. Second, families who can afford to send their children to schools that require large shares of private funding may tend to have other, often unobserved features conducive to the children's learning. For example, they may show a greater valuation of educational outcomes per se, or they may simply use their larger income also to buy private afternoon lessons for their children if they are underperforming in a given subject. Therefore, the selection bias due to credit constraints would generally make privately funded schools look better than they really are. Thus, we would expect this particular source of bias to affect estimates of funding effects rather than operation effects, and we would expect this bias to point in the direction that publicly funded schools look worse than they are. In what follows, we depict these ideas more formally, before we go on to discuss other possible sources of remaining bias.

Consider first the observable background features $B$. Following the above-mentioned theories of credit constraints, it seems reasonable to assume that $B$ will be positively related with the share of private funding in the school, i.e. negatively related with $F$. Therefore, there will be non-zero elements in the covariance matrix between the $B$ features and $F$. But if $F^{\prime} B \neq$ 0 , estimating the effect of $F$ under disregard of controls for $B$ will yield a biased estimate of the true effect $\beta_{2}$ of equation (1). However, given that we assume $B$ to be observable, we can easily control for $B$ in our regression, so that the estimated effect is no longer biased by the observables. This is the reason why we include an unusually extensive set of controls for background factors $B$ in all our empirical specifications. Specifically, the control vector $B$ of background data encompasses 60 variables, including 8 variables on student characteristics, 28 variables on students' family background, 14 variables on resource inputs at home and at school and 10 variables on institutional features of the school system. ${ }^{7}$

7 The 8 control variables on student characteristics are: student gender, student age and 6 dummies for grade level (ranging from $6^{\text {th }}$ to $12^{\text {th }}$ grade). The 28 control variables on family background are: 5 dummies for parental education (representing no education, primary, lower secondary, two types of upper secondary, and university education), one dummy each on the migration status of father, mother and student, 3 dummies on family status (representing whether the student lives with no parent, single father, single mother, or both parents), 3 dummies on parents' work status (at least one half-time, at least one full-time, both full-time, reference category: none working), 2 dummies on parental occupation (blue and white collar), 6 dummies on the number of books at home, 5 dummies on the school's community location (ranging from small village to huge city) and the country's GDP per capita. The 14 control variables on resource inputs are: class size in the subject, educational expenditure per student in the country, 2 dummies on availability of instructional material (not at all lacking, strongly lacking), 3 dummies on teacher education (masters in pedagogy, teacher certificate, and masters in the respective subject), instruction time, 2 dummies on homework time in the subject (1-3 hours and more than 3 hours per week), 2 dummies on parental support (not at all lacking, strongly lacking) and 2 dummies on computer availability at home (one computer, more than one). The 10 control variables on institutions are: external exit exams, standardized tests and 8 dummies on school autonomy in determining 
Now, consider the unobserved background features $U$. If the covariance matrix $F^{\prime} U \neq 0$, estimating the funding effect under disregard of controls for $U$ yields the following biased estimate $\gamma$, using the standard formula for omitted-variable bias (cf., e.g., Greene 2000, p. 334):

$$
E(\gamma)=\beta_{2}+\left[\left(F_{s} F_{s}\right)^{-1} F_{s}^{\prime} U_{i}\right] \beta_{4}
$$

Assuming for the moment only one unobserved variable $U_{i}$, we can also write:

$$
E(\gamma)=\beta_{2}+\frac{\operatorname{cov}\left(F_{s}, U_{i}\right)}{\operatorname{var}\left(F_{s}\right)} \beta_{4} .
$$

This derivation allows us to pin down the likely direction of the bias that emanates from credit constraints. The estimate $\gamma$ will be lower than the true effect $\beta_{2}$ of equation (1) if $\beta_{4}$ is positive and $\operatorname{cov}\left(F_{s}, U_{i}\right)$ is negative. And this is likely to be the case in this particular application. Let's say that $U_{i}$ is (unmeasured) parents' valuation of education. Then $\beta_{4}$ is positive, i.e. parents' valuation of education has a positive impact on their children's educational performance. And $\operatorname{cov}\left(F_{s}, U_{i}\right)$ is negative, because parents' valuation of education is positively associated with their willingness (and probably ability) to provide private funding, i.e. negatively related to the share of public funding in their school. Therefore, the estimate $\gamma$ will be a lower bound for the true effect $\beta_{2}$. The larger the covariance between the unobserved features $U$ and the share of private funding, and the larger the effect $\beta_{4}$ of the unobserved features on student performance, the larger will be the underestimation of the effect of public funding. However, once we allow for multiple unobserved variables, the uniqueness of this result is no longer given.

Note also that there may be other possible sources of remaining bias than credit constraints. Although credit constraints are often viewed as the main cause of concern for selectivity in education, other unobservable features may give rise to different kinds of bias. As one example, the selection may not only originate on the student/parent side, but also on the school side. If privately operated schools have more freedom to choose their students, and if the selected students have features unobserved by the researcher that differ from those of students in publicly operated schools, then this may give rise to bias also on the operation

course content, in choosing textbooks, in formulating the school budget, in deciding on budget allocations, in hiring teachers, in firing teachers, in establishing teachers' starting salaries and in establishing teachers' salary increases. See Fuchs and Wößmann (2004) for details. 
side. For example, privately operated schools may have a preference to admit students who are particularly smart for their observable features, which would bias the coefficient estimate on $O$ downwards. Moreover, in empirical applications that use variation across countries, there may be unobserved country features that are associated with the share of public operation and funding in a non-random way. Therefore, the extent and direction of any remaining bias must ultimately remain an open issue.

\subsection{Alternative Empirical Specifications}

Altogether, in this paper we will estimate six different versions of the basic empirical model. In specification (4), the variables on public vs. private involvement are measured at the country level and entered in a cross-country regression performed at the student level:

$$
T_{i}=\alpha+\beta_{1} O_{c}+\beta_{2} F_{c}+B_{i} \beta_{3}+v_{c}+\eta_{s}+\varepsilon_{i},
$$

where $O_{c}$ and $F_{c}$ are the share of publicly operated schools and the average share of public funding of schools in country $c$, respectively. Both student test scores $T_{i}$ and background features $B_{i}$ are measured at the student level (the school characteristics in $B$ at the school level), so as to yield as clean a control for other influence factors as possible. Note that in the empirical application, the error term will have higher-level components at the school and country level, whose implementation will be discussed in Section 4.3 below.

The reason why we start with a cross-country specification with country-level publicprivate data is the possibility discussed in Section 3 above that the mere existence of private schools in a city may have systemic effects due to their effect on how the public schools in the city perform, because these public schools are now faced with competition from private schools. Thus, looking at the simple relative performance of privately and publicly operated schools may well fail to observe the effects of the existence of the privately operated school. By contrast, such systemic effects will be captured in the specification that measures private involvement at the level of the country. The specification shows whether countries with a larger sector of publicly operated schools and with a larger share of public funding fare differently on average on the PISA test than countries with larger shares of private involvement.

A second advantage of the specification is that it evades the problem of selection bias just discussed. While it may be the case that students whose performance differs for other reasons may select (or be selected) into private schools in non-random ways, such selection effects will cancel out at the country level. Under the quite confident assumption that there is no 
school selection across country borders of an order of magnitude that might affect the presented results, any non-random selection would occur within the observation level of the public-private measures in specification (4) and would therefore not affect the estimates of $\beta_{1}$ and $\beta_{2}$ in this specification. Note, though, that one can never perfectly rule out remaining endogeneity due to unobservables at the country level.

Specification (5) simplifies the picture even further, by classifying the countries into the four quadrants of Figure 1 established by the shares of public operation and public funding. That is, public-private involvement will be measured just by attributing dummies to the countries whether they belong to the top left $(T L)$, the bottom left $(B L)$ or the bottom right $(B R)$ quadrant of Figure 1, where the reference category is the top right quadrant:

$$
T_{i}=\alpha+\beta_{1} T L_{c}+\beta_{2} B L_{c}+\beta_{3} B R_{c}+B_{i} \beta_{4}+v_{c}+\eta_{s}+\varepsilon_{i}
$$

This quadrant-dummy specification has the same advantages as the specification with country-level public-private data, only that it provides the results in an even simpler (but also coarser) way: Does the performance of the countries in the four quadrants of Figure 1 differ systematically from each other?

Specification (6) adds an interaction term between public operation and public funding to specification (4):

$$
T_{i}=\alpha+\beta_{1} O_{c}+\beta_{2} F_{c}+B_{i} \beta_{3}+\left(O_{c} F_{c}\right) \beta_{4}+v_{c}+\eta_{s}+\varepsilon_{i}
$$

The coefficient on the interaction term $\left(O_{c} F_{c}\right)$ depicts whether any effect of public funding $F$ differs between countries with lower or higher shares of publicly operated schools.

The next specification makes use of the individual-level data of public-private involvement in schools. That is, both public operation $O_{s}$ and public funding $F_{s}$ are now measured at the level of each school $s$, still in a regression encompassing all countries:

$$
T_{i}=\alpha+\beta_{1} O_{s}+\beta_{2} F_{s}+B_{i} \beta_{3}+\left(O_{s} F_{s}\right) \beta_{4}+\eta_{s}+\varepsilon_{i} \text {. }
$$

Note that $O_{s}$ is now a dummy representing whether the student's school is publicly (as opposed to privately) operated, while $F_{s}$ is the share of public funding of the school.

In this specification, the considerations on possible selection bias now come into play, which suggested that one particularly relevant source of bias, due to credit constraints, points in the direction that the estimate $\beta_{2}$ on the effect of public funding may be biased downwards, i.e. biased in favor of schools with larger shares of private funding. The specification can again be estimated with and without an interaction effect. In the specification using school- 
level data on public-private involvement, the coefficient on the interaction term depicts whether any association between student performance and public funding $F$ differs between publicly and privately operated schools.

Specification (8) adds country fixed effects to specification (7):

$$
T_{i}=\alpha_{c}+\beta_{1} O_{s}+\beta_{2} F_{s}+B_{i} \beta_{3}+\left(O_{s} F_{s}\right) \beta_{4}+\eta_{s}+\varepsilon_{i}
$$

where $\alpha_{c}$ is a country-specific intercept implemented by adding a full set of controls for country dummies. By disregarding any variation that exists between countries, this specification in effect estimates the average effect of public operation and funding within the countries in the pooled dataset. That is, the specification shows whether on average, publicly operated and publicly funded schools in a country fare differently from privately operated and privately funded schools in the same country. The previous considerations suggest that the relative importance of selection bias may get ever more severe in this specification, because the selection-free variation that exists between countries is now no longer considered.

Finally, specification (9) estimates the same specification separately within each country $c$ :

$$
\forall c: \quad T_{i}=\alpha+\beta_{1} O_{s}+\beta_{2} F_{s}+B_{i} \beta_{3}+\eta_{s}+\varepsilon_{i} \quad \text { if } i \in C .
$$

By doing so, this specification can depict whether the within-country associations between public-private involvement and student performance are heterogeneous across the countries. The presented results on this specification will not consider an interaction term $\left(O_{s} F_{s}\right)$, because initial experimentation showed that samples seem to get too small in most countries to properly identify the interaction effect within individual countries.

\subsection{Specifics of the Microeconometric Model}

As indicated before, the error term of the regression has a non-trivial structure because of the complex data structure produced by the PISA survey design and the multi-level nature of the explanatory variables. Given the possible dependence of students within the same school, the use of school-level variables and the fact that schools were the primary sampling unit (PSU) in PISA (cf. Adams and Wu 2002), the independence assumption usually made with respect to individual observations in standard econometric methods should be relaxed in favor of the assumption that only the variation between schools (PSUs) provides independent variation (cf. Moulton 1986). This is implemented by the clustering-robust linear regression (CRLR) method, which allows any given amount of correlation of the error terms within PSUs and 
requires only that observations be independent across PSUs (cf. White 1984; Deaton 1997). For variables measured at the country level, we even allow for clustering by country.

PISA used a stratified sampling design within each country, producing varying sampling probabilities for different students. To obtain nationally representative estimates from the stratified survey data at the within-country level, we employ weighted least squares (WLS) estimation using sampling probabilities as weights. WLS estimation ensures that the proportional contribution to the parameter estimates of each stratum in the sample is the same as would have been obtained in a complete census enumeration (DuMouchel and Duncan 1983; Wooldridge 2001). Furthermore, at the between-country level, our weights give equal weight to each country.

\section{Empirical Results on Public-Private Division and Student Achievement}

This section presents the empirical results on the association between PPPs and student achievement. It shows how student performance is associated with public vs. private involvement in the operation and funding of schools both across and within countries.

\subsection{Public vs. Private Funding and Operation Measured at the Country Level}

The specifications (4) and (5) that use only the variation between countries and disregard variation within countries by aggregating the measures of public-private involvement at the country level have the advantages of capturing system-level effects and of evading withincountry selection biases. Column (Q) in Table 4 presents the results of the quadrant-dummy specification (5) for math performance. This specification compares student performance in the four basic system types of Figure 1, with the type representing the largest number of countries, the top right quadrant of systems with large public shares in both operation and funding, serving as the reference category. ${ }^{8}$

The results show that there are large and statistically significant systematic performance differences between systems that make strong use of PPPs and systems that do not. Systems with a relatively low share of public operation, but large share of public funding perform best. Their average performance is 37.9 PISA test-score points higher than the average performance of systems that are mainly publicly operated and funded. Given that the test

8 Note that given the somewhat arbitrary subdivision into the four quadrants of Figure 1, this quadrantdummy specification is meant as a depiction of a broad pattern only. It receives its validity only from the fact that the depicted pattern is vindicated by the richer specification reported below where public operation and public funding are entered as linear variables. 
Table 4: Public-Private Involvement and Math Performance across Countries

\begin{tabular}{|c|c|c|c|c|c|c|c|c|c|}
\hline & \multicolumn{5}{|c|}{ Country-level public-private measures } & \multicolumn{4}{|c|}{ School-level public-private measures } \\
\hline & $(\mathrm{Q})$ & (R) & (S) & (T) & (U) & (V) & (W) & $(\mathrm{X})$ & $(\mathrm{Y})$ \\
\hline Top left quadrant & $\begin{array}{l}37.93^{* * *} \\
(12.52)\end{array}$ & & & & & & & & \\
\hline Bottom left quad. & $\begin{array}{r}0.02 \\
(7.73)\end{array}$ & & & & & & & & \\
\hline Bottom right quad. & $\begin{array}{l}-36.64^{* * *} \\
(8.17)\end{array}$ & & & & & & & & \\
\hline Public operation & & $\begin{array}{l}-74.55^{* * *} \\
(14.78)\end{array}$ & & $\begin{array}{l}-93.80^{* * *} \\
(13.81)\end{array}$ & $\begin{array}{c}-193.15^{* *} \\
(94.26)\end{array}$ & $\begin{array}{l}-19.68^{* * *} \\
(2.40)\end{array}$ & & $\begin{array}{l}-24.69^{* * *} \\
(2.69)\end{array}$ & $\begin{array}{r}-9.05 \\
(5.98)\end{array}$ \\
\hline Public funding & & & $\begin{array}{r}24.51 \\
(26.69)\end{array}$ & $\begin{array}{c}91.05^{* * *} \\
(27.03)\end{array}$ & $\begin{array}{r}3.73 \\
(77.00)\end{array}$ & & $\begin{array}{r}1.64 \\
(3.53)\end{array}$ & $\begin{array}{l}18.56^{* * *} \\
(3.96)\end{array}$ & $\begin{array}{l}30.18^{* * *} \\
(6.40)\end{array}$ \\
\hline Interaction & & & & & $\begin{array}{r}113.45 \\
(109.86) \\
\end{array}$ & & & & $\begin{array}{l}-20.37^{* * *} \\
(7.63) \\
\end{array}$ \\
\hline Observations & 72,493 & 72,493 & 72,493 & 72,493 & 72,493 & $\begin{array}{r}72,493 \\
0\end{array}$ & $\begin{array}{r}72,493 \\
20\end{array}$ & $\begin{array}{r}72,493 \\
0\end{array}$ & $\begin{array}{r}72,493 \\
0\end{array}$ \\
\hline Strata & & & & & & 29 & 29 & 29 & 29 \\
\hline PSUs & 29 & 29 & 29 & 29 & 29 & 4,870 & 4,870 & 4,870 & 4,870 \\
\hline$R^{2}$ & 0.314 & 0.309 & 0.293 & 0.315 & 0.316 & 0.297 & 0.293 & 0.298 & 0.298 \\
\hline
\end{tabular}

Notes: Dependent variable: PISA international math test score. Least-squares regressions weighted by students' sampling probabilities. Regressions include 60 control variables for student, family and school characteristics. Robust standard errors adjusted for clustering in parentheses (columns (Q) to (U): clustering by country; columns (V) to (Y): clustering by school). Quadrant dummies refer to country's position in Figure 1. Interaction = interaction term between public operation and public funding.

Significance level (based on clustering-robust standard errors): ${ }^{* *} 1$ percent. ${ }^{* *} 5$ percent. ${ }^{*} 10$ percent.

Source: Own calculations based on PISA micro database. 
scores are scaled to have an international standard deviation among the OECD countries of 100 , the effect size can be interpreted as percentage points of an international standard deviation. That is, PPP systems that combine public funding with private operation perform more than one third of an international standard deviation better than pure public systems. To provide an alternative benchmark for the size of this performance difference, we can also compare it to the unconditional performance difference between $9^{\text {th }}$-grade and $10^{\text {th }}$-grade students (the two largest grades in PISA), which is 30.3 PISA test-score points in math. ${ }^{9}$ That is, 15-year-old students in public-funding private-operation PPP systems on average perform more than the equivalent of a whole grade level better than same-aged students in mainly publicly funded and operated systems.

By contrast, students in systems that combine large shares of public operation with relatively low shares of public funding, i.e. the second type of PPP, perform 36.6 test-score points worse than students in purely public systems. Interestingly, there is no difference at all in the average performance of students in systems that combine large shares of private operation and funding and students in systems that combine large shares of public operation and funding.

Figure 2 depicts the result pattern graphically. It shows that the two forms of PPPs - public funding with private operation and public operation with private funding - have diametrically opposite consequences relative to all-public or mainly-private systems. The performance difference between the two forms of PPPs adds up to 74.6 points. These results suggest that it makes a fundamental difference how the partnership between public and private in PPPs is conceived: Reserving funding for the public side but contracting the operation to the private sector brings huge gains in performance, but transferring funding to the private side and leaving the operation of schools in the public hand brings huge losses. The picture also suggests that there are no significant interactions between operation and funding at this level: Public operation has a negative effect, independent of the mode of funding, and public funding has a positive effect, independent of the mode of operation. Therefore, in a mainly privately operated and funded system, the two effects cancel out and average performance is similar to a mainly publicly operated and funded system.

The basic pattern of results is exactly the same in the other two subjects, reading and science, as the results reported in columns (Z) and (AE) in Table 5 show. The size of the performance differences in these two subjects is somewhat lower, though, and there are slight

\footnotetext{
9 The values in reading and science are 33.2 and 32.4, respectively.
} 
Figure 2: Student Achievement in the Four Quadrants of Public-Private Involvement

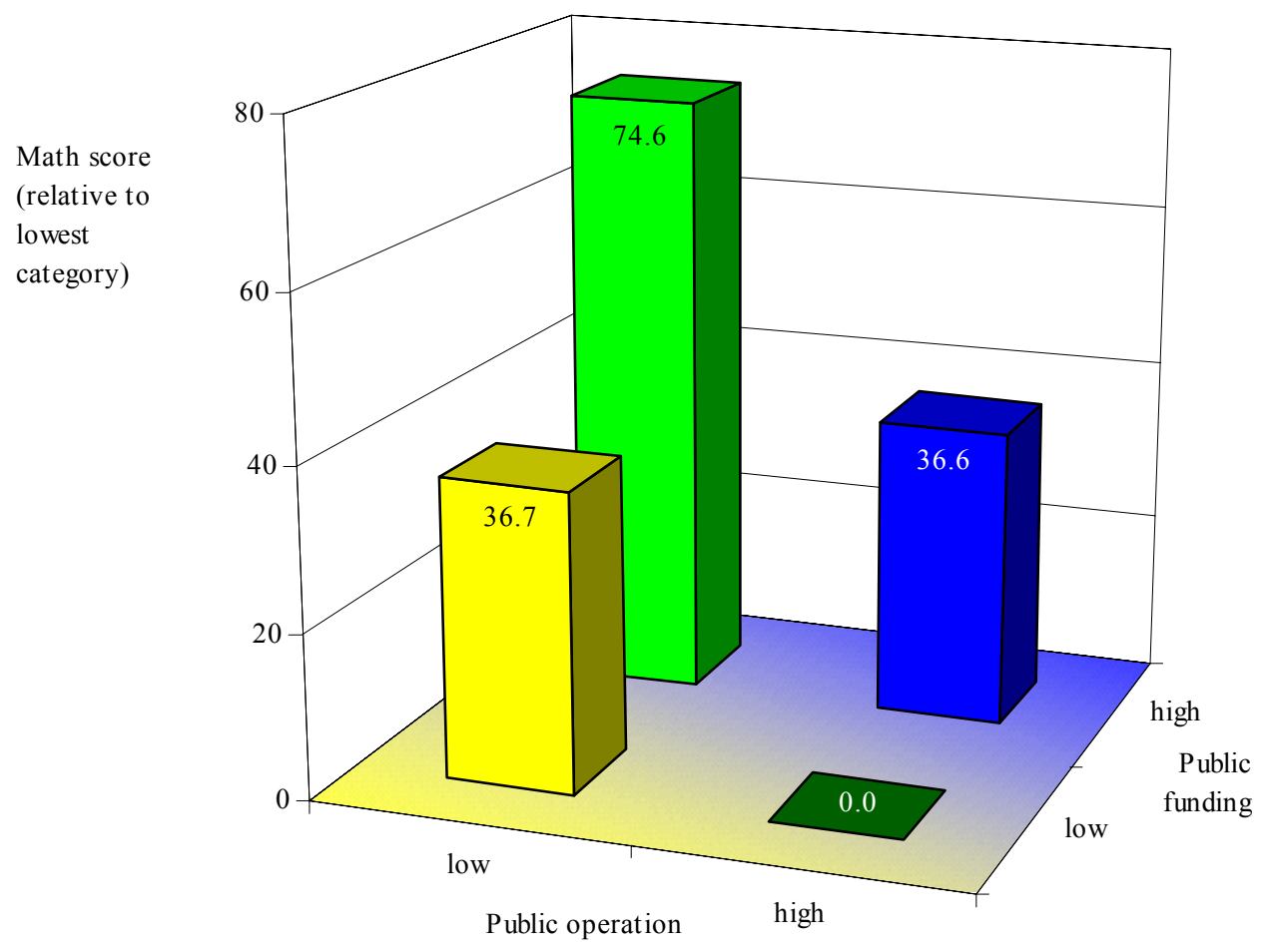

Notes: The distinction into countries with relatively low and relatively high shares of public operation and funding follows the quadrants in Figure 1.

Source: Table 4, column (Q). 
Table 5: Public-Private Involvement and Performance in Reading and Science across Countries

\begin{tabular}{|c|c|c|c|c|c|c|c|c|c|c|}
\hline & \multicolumn{5}{|c|}{ Reading } & \multicolumn{5}{|c|}{ Science } \\
\hline & \multicolumn{3}{|c|}{$\begin{array}{l}\text { Country-level public- } \\
\text { private measures }\end{array}$} & \multicolumn{2}{|c|}{$\begin{array}{l}\text { School-level public- } \\
\text { private measures }\end{array}$} & \multicolumn{3}{|c|}{$\begin{array}{l}\text { Country-level public- } \\
\text { private measures }\end{array}$} & \multicolumn{2}{|c|}{$\begin{array}{l}\text { School-level public- } \\
\text { private measures }\end{array}$} \\
\hline & $(\mathrm{Z})$ & $(\mathrm{AA})$ & $(\mathrm{AB})$ & $(\mathrm{AC})$ & (AD) & $(\mathrm{AE})$ & $(\mathrm{AF})$ & $(\mathrm{AG})$ & $(\mathrm{AH})$ & $(\mathrm{AI})$ \\
\hline Top left quadrant & $\begin{array}{l}28.28^{* *} \\
(10.45)\end{array}$ & & & & & $\begin{array}{r}17.00 \\
(12.45)\end{array}$ & & & & \\
\hline Bottom left quad. & $\begin{array}{r}-9.56 \\
(6.39)\end{array}$ & & & & & $\begin{array}{r}5.86 \\
(6.61)\end{array}$ & & & & \\
\hline Bottom right quad. & $\begin{array}{l}-13.06^{* *} \\
(5.76)\end{array}$ & & & & & $\begin{array}{l}-18.36^{* * *} \\
(6.53)\end{array}$ & & & & \\
\hline Public operation & & $\begin{array}{l}-56.95^{* * *} \\
(10.71)\end{array}$ & $\begin{array}{l}-35.15 \\
(70.13)\end{array}$ & $\begin{array}{l}-19.27^{* * *} \\
(2.30)\end{array}$ & $\begin{array}{l}-7.04 \\
(4.88)\end{array}$ & & $\begin{array}{l}-55.61^{* * *} \\
(11.86)\end{array}$ & $\begin{array}{l}-183.89^{* *} \\
(80.54)\end{array}$ & $\begin{array}{l}-17.94^{* * *} \\
(2.42)\end{array}$ & $\begin{array}{l}-6.31 \\
(5.01)\end{array}$ \\
\hline Public funding & & $\begin{array}{l}59.06^{* *} \\
(23.62)\end{array}$ & $\begin{array}{r}78.07 \\
(59.05)\end{array}$ & $\begin{array}{l}8.35^{* *} \\
(3.29)\end{array}$ & $\begin{array}{l}17.42^{* * *} \\
(5.37)\end{array}$ & & $\begin{array}{r}22.07 \\
(20.49)\end{array}$ & $\begin{array}{r}-90.88 \\
(66.11)\end{array}$ & $\begin{array}{r}0.79 \\
(3.36)\end{array}$ & $\begin{array}{r}9.39^{*} \\
(5.24)\end{array}$ \\
\hline Interaction & & & $\begin{array}{r}-24.80 \\
(84.64) \\
\end{array}$ & & $\begin{array}{l}-15.91^{* *} \\
(6.30) \\
\end{array}$ & & & $\begin{array}{r}146.01 \\
(94.11) \\
\end{array}$ & & $\begin{array}{l}-15.11^{* *} \\
(6.41) \\
\end{array}$ \\
\hline Observations & 130,242 & 130,242 & 130,242 & 130,242 & 130,242 & 72,388 & 72,388 & 72,388 & 72,388 & 72,388 \\
\hline Strata & & & & 29 & 29 & & & & 29 & 29 \\
\hline PSUs & 29 & 29 & 29 & 4,882 & 4,882 & 29 & 29 & 29 & 4,870 & 4,870 \\
\hline$R^{2}$ & 0.310 & 0.311 & 0.311 & 0.306 & 0.306 & 0.254 & 0.256 & 0.257 & 0.252 & 0.252 \\
\hline
\end{tabular}

Notes: Dependent variable: PISA international reading/science test score. Least-squares regressions weighted by students' sampling probabilities. Regressions include 60 control variables for student, family and school characteristics. Robust standard errors adjusted for clustering in parentheses (columns $(\mathrm{Z})$ to $(\mathrm{AB})$ and $(\mathrm{AE})$ to $(\mathrm{AG})$ : clustering by country; columns $(\mathrm{AC})$, $(\mathrm{AD}),(\mathrm{AH})$ and $(\mathrm{AI})$ : clustering by school). Quadrant dummies refer to country's position in Figure 1 . Interaction $=$ interaction term between public operation and public funding.

Significance level (based on clustering-robust standard errors): ${ }^{* * *} 1$ percent. ${ }^{* *} 5$ percent. ${ }^{*} 10$ percent.

Source: Own calculations based on PISA micro database. 
but statistically insignificant differences in the size of the estimate on the coefficient on the bottom left quadrant.

The very same pattern of negative effects of public operation and positive effects of public funding emerges in specification (4) with country-level data on public-private operation and funding. As the results reported in columns (T), (AA) and (AF) in Tables 4 and 5 reveal, the coefficient on public operation is statistically significantly negative in all three subjects, and the coefficient on public funding is positive in all three subjects and statistically significantly so in math and reading. ${ }^{10}$ Note that the positive coefficient on public funding in math is significant only once the mode of operation is controlled for (compare columns (R), (S) and $(\mathrm{T}))$.

\subsection{Cross-Country Regressions with School-Level Public-Private Measures}

Columns (X), (AC) and (AH) in Tables 4 and 5 report the results of specification (7) that uses individual-level data on public-private involvement, first without an interaction term. ${ }^{11}$ Note that the difference between this and the previous specifications is not in the level of estimation, because all specifications use student-level data on test scores and background features. The difference is in the level at which the measures of public vs. private operation and funding of schools are measured.

The qualitative results of the specification measuring public-private involvement at the school level are the same as those of the specification with country-level public-private measures in all three subjects: Public operation is negatively associated with student achievement and public funding is positively associated with student achievement. As argued in Section 4.1 above, the selection bias due to credit constraints is likely to bias the estimate on public funding in the specification with school-level public-private measures downwards. However, we still get a statistically significant positive estimate. Therefore, the effect of public funding on student achievement seems indeed to be positive, and likely to be even larger than the reported coefficient estimates of this specification suggest. This pattern is also consistent with the relative size of the coefficient estimate in the specifications with countrylevel and school-level public-private measures. The lower size in the specification with

10 The results on public operation are consistent with evidence from a previous international student achievement test, TIMSS, showing that student performance was superior in countries with a larger share of private enrollment and with a larger share of public funding going to privately operated schools (Wößmann 2001, 2003).

11 This specification and the results are very similar to those reported in Fuchs and Wößmann (2004). 
school-level public-private measures could be attributed to the selection bias due to credit constraints, which is operative within countries but not across countries. But obviously, selection biases stemming from other sources may also be at play.

The coefficient estimate on public operation is also smaller in absolute terms in the specification with school-level public-private measures. As argued above, theories of credit constraints would not predict a bias of the coefficient on public vs. private operation. By contrast, such a bias could, for example, be attributed to non-random selection of students on part of the privately operated schools. However, note that most standard versions of selection bias would predict a difference in the coefficient estimates of the two specifications that would go the other way, pushing the coefficient in the specification with school-level publicprivate measures even more into the negative.

In sum, all specifications that use the cross-country variation, both using country-level and school-level measures of public-private involvement, yield the result that public operation has a negative and public funding a positive effect on student performance.

\subsection{Interactions between Funding and Operation}

To see whether the effect of public funding differs under public vs. private operation of schools, the next specification adds an interaction term between operation and funding to the model. Columns (U), (AB) and (AG) in Tables 4 and 5 report results of specification (6) that adds the interaction term to the country-level measure specification (4). As already apparent in the quadrant-dummy specification depicted in Figure 2, there is no significant interaction effect in any of the subjects in this specification with country-level public-private data, which in this specification is mainly due to the fact that the estimates have large standard errors and thus lack statistical power.

But the interaction results are different in specification (7) that estimates the interaction term on individual-level data on public-private involvement, reported in columns (Y), (AD) and (AI). In all three subjects, the interaction term is statistically significantly negative. This means that public operation has a slightly negative effect already in schools with low public funding, but this effects gets ever more negative with increasing public funding. This pattern is depicted graphically in panel (a) of Figure 3. The pattern might either be driven by increasing lack of accountability in schools that do not receive any private funding, or it may be driven by the selection bias of higher-performing students into schools with larger shares of private funding. 
Figure 3: The Interaction of Public Operation and Public Funding

(a) Effect of public operation depending on type of funding

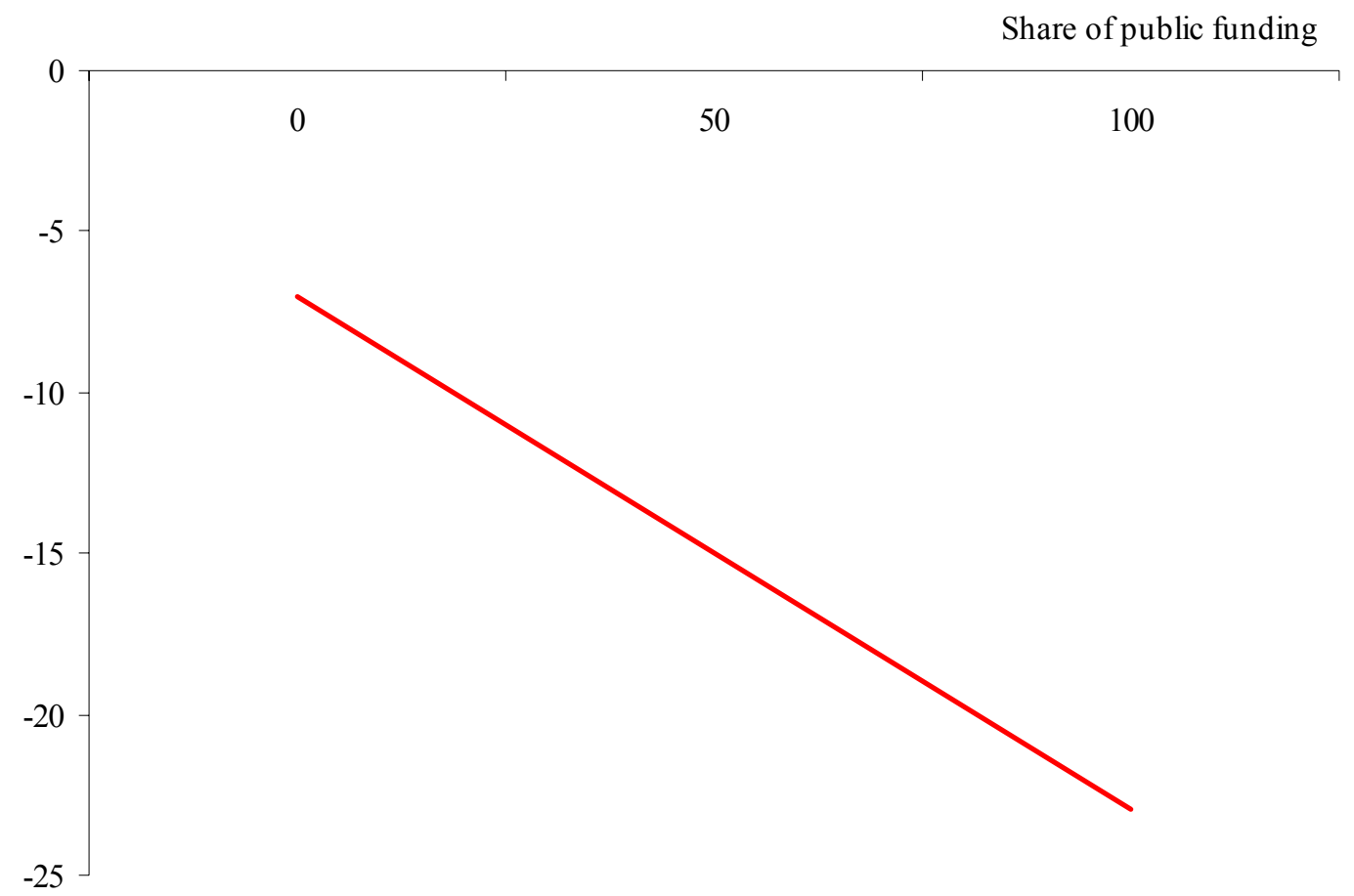

Effect of public operation on reading score

(b) Effect of public funding depending on type of operation

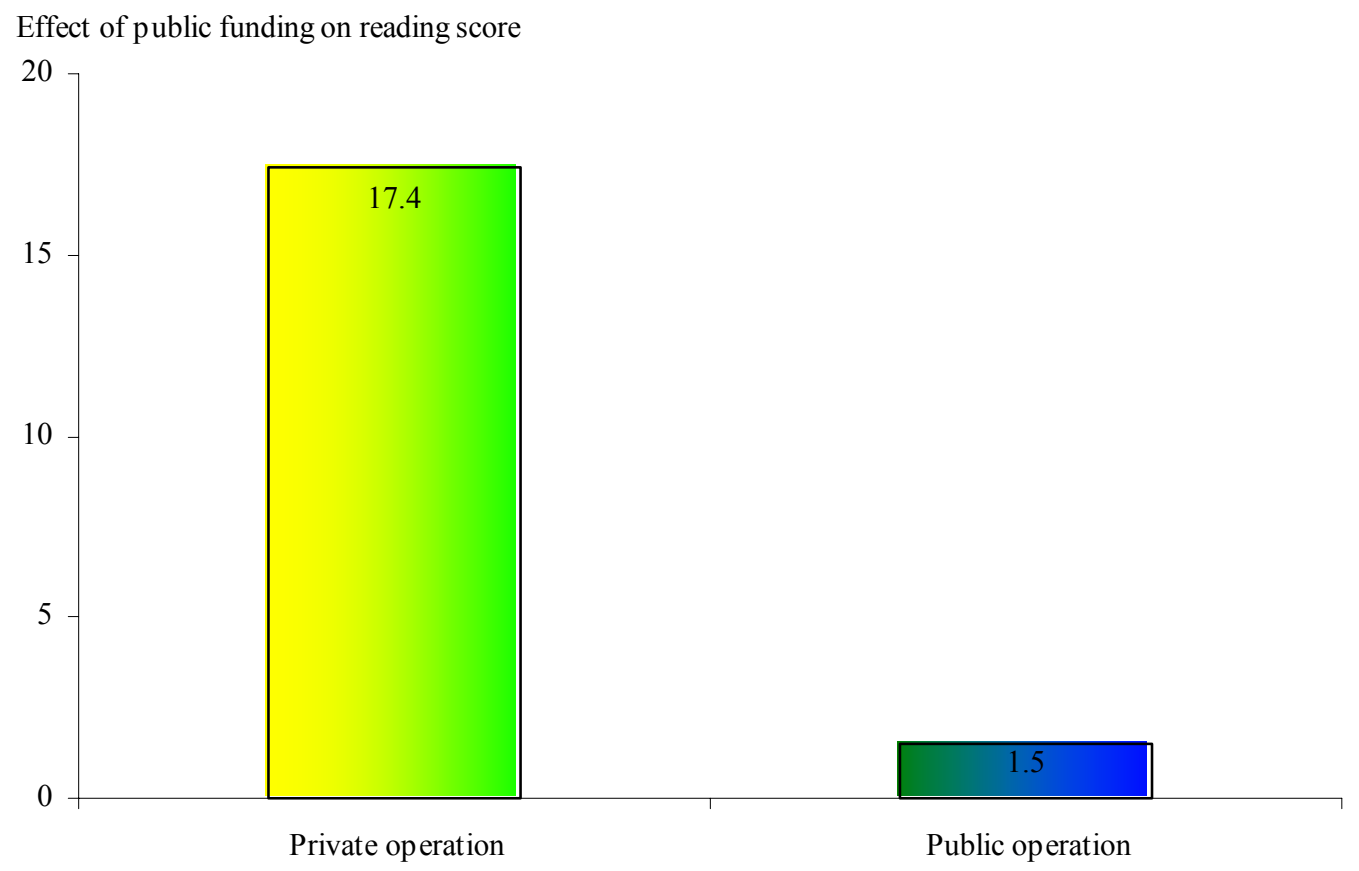

Source: Table 5, column (AD). 
At the same time, the negative interaction term means that the positive effect of public funding is strongly concentrated in schools that are privately operated, while the effect of public funding reduces to about zero in publicly operated schools (cf. panel (b) of Figure 3). This pattern might suggest that it is particularly the role of public funding in allowing everyone - including low-income families - to opt for privately operated schools that drives the positive association between public funding and student performance. In this sense, public funding can enable more choice, in that families that would otherwise be credit constrained can choose privately operated schools if funding comes from public sources.

\subsection{Regressions Using Only Variation within Each Country}

Results of specification (8), which adds country fixed effects to the previous specification (7), are reported in the top panel of Table 6. An interaction term between public funding and operation was never statistically significant in the three subjects and was thus dropped from the specification. In this specification that disregards the between-country variation and exploits only the within-country variation, the coefficients on both public operation and public funding are negative, and the coefficient on public funding is the larger one in absolute terms. This might suggest that the association between public funding and student performance within countries is mostly driven by the selection bias of higher-performing children into schools with larger shares of private funding. However, this specification using the within-country variation in the pooled cross-country dataset also foreshadows systematic differences in the associations between countries.

This becomes apparent in the lower panels of Table 6, which report results of estimating the model separately for each country, as in specification (9). ${ }^{12} \mathrm{We}$ restrict our attention to reading performance here because the reading samples are substantially larger than the samples in the other two subjects, which becomes particularly relevant when restricting the estimations to within each country. It should still be recognized that in some countries, cell sizes get worryingly small, as is evident from the small number of privately operated schools in some country samples, reported in column (I) in Table 1.

12 Previous studies have estimated similar models of the effects of private school operation within several countries from international achievement tests, but without accounting for differences in the source of school funding. Thus, Toma (1996; cf. also 2005) estimates the effect of private school operation in five countries using the 1981 second international mathematics test. She notes that the positive effect of private provision is independent of whether the countries tend to finance the schools publicly or not. Vandenberghe and Robin (2004) estimate the effect of private school operation in eight countries in PISA, comparing several estimation methods that try to address selection bias, but disregarding the funding side of schools. 
Table 6: Estimations within Countries

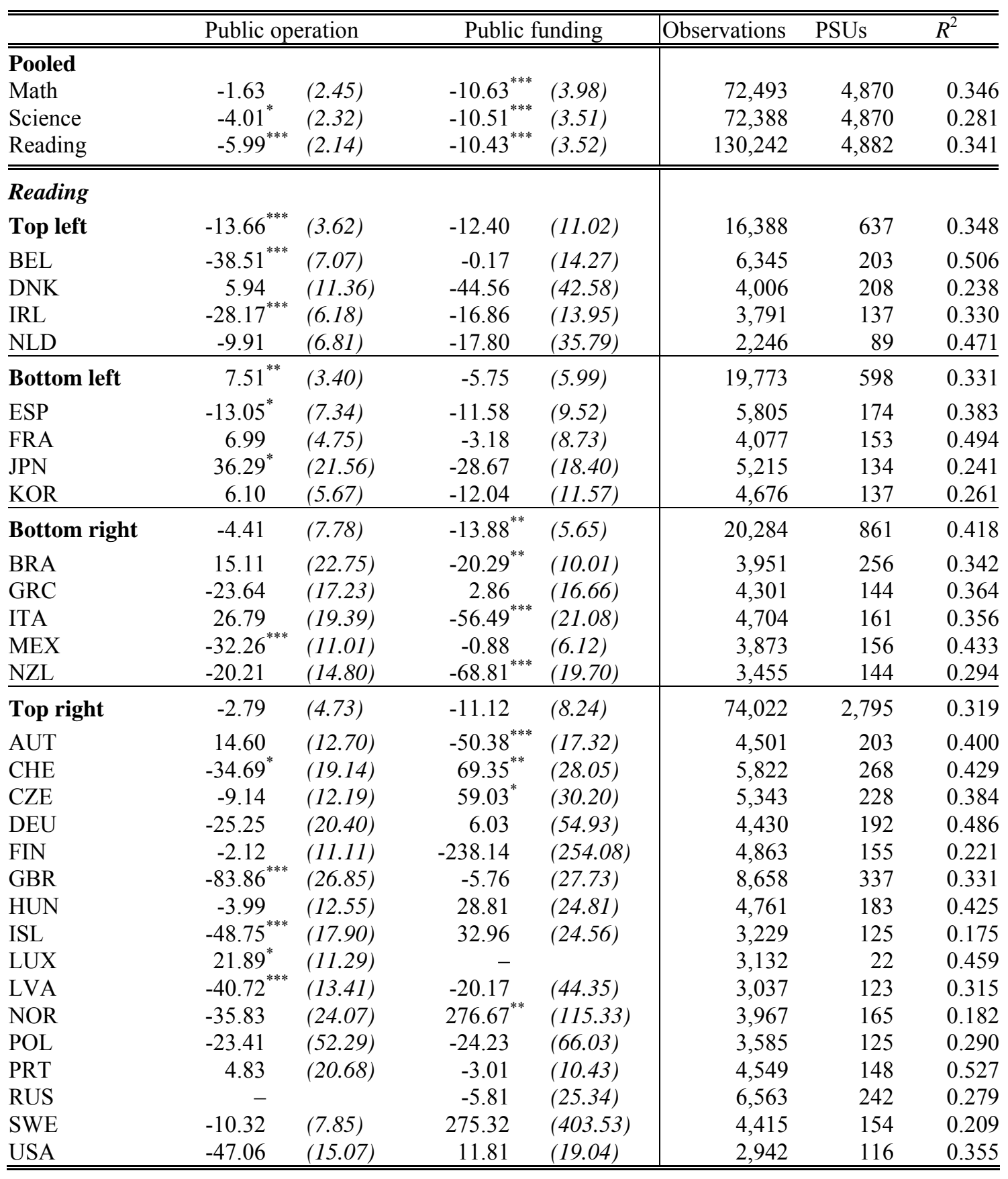

Notes: Dependent variable: PISA international test score. Least-squares regressions weighted by students' sampling probabilities. Regressions include 60 control variables for student, family and school characteristics. Robust standard errors adjusted for clustering in parentheses (clustering by school). Regressions that pool countries control for country fixed effects. The organization of countries follows the four quadrants of Figure 1. See notes to Figure 1 for a list of country acronyms.

Significance level (based on clustering-robust standard errors): ${ }^{* *} 1$ percent. ${ }^{* *} 5$ percent. ${ }^{*} 10$ percent.

Source: Own calculations based on PISA micro database. 
A broad systematic pattern emerges when we look at the countries separately by their affiliation to the four quadrants of Figure 1 again. Running the pooled within-country regressions separately for each quadrant (again including country fixed effects), it becomes apparent that the negative coefficient on public operation in the specification pooling all countries is mainly driven by the countries in the top left panel, while the negative coefficient on public funding is mainly driven by the countries in the bottom right panel. All other panelwise coefficients are statistically insignificant, which may be partly due to a substantially smaller statistical power relative to the pooled cross-country analyses because of the smaller number of observations. ${ }^{13}$ Note that the lower performance of publicly operated schools in the top left quadrant is unlikely to be caused by credit-constraint-based selection patterns, as all schools in the systems of this quadrant - be they publicly or privately operated - receive the vast majority of their funding from public sources.

By contrast, the lower performance of schools with larger shares of public funding in the countries of the bottom right quadrant may well be driven by credit-constraint-based selection bias. Nearly all schools in the systems of this quadrant are publicly operated, but rich families, whose children may perform better for reasons other than the public-private division of school operation and funding, can provide additional private funding for their schools. Finally, note that in the top right quadrant, there is a statistically significant negative association of student achievement with public school operation and a statistically significant positive association with the share of public school funding in several countries, as is the pattern in the specifications using the cross-country variation.

Still, it should be borne in mind that the specifications using the variation within each country face the fundamental problem of selection bias. In particular, credit constraints might be expected to bias the estimates on public funding in the negative direction.

\section{Conclusion}

This paper has presented cross-country evidence on the effectiveness of public-private partnerships (PPPs) in providing cognitive skills to students. The main result is that across countries, public operation of schools is negatively associated with student performance in math, reading and science, while public funding of schools is positively associated with student performance in the three subjects. This suggests that school systems based on PPPs in

13 The positive coefficient on public operation in the bottom left quadrant is driven by the highly imprecise estimate in Japan. 
the sense that the state finances schools but contracts their operation out to the private sector are the most effective school systems. By contrast, school systems based on PPPs in the sense that they require a lot of private funding but keep the operation of schools in the public sector fare even worse than systems where operation and funding is either both public or both private. Thus, the results favor the particular form of educational PPPs where the state does the funding and the private sector runs the schools.

While this paper has looked at the relative effectiveness of PPPs in providing cognitive skills, aspects of efficiency, equity and non-cognitive skills have been left for future research. To look at the relative efficiency of PPPs, defined in terms of output per input, one would have to add a comparison of the costs at which PPPs operate relative to mere-public or mereprivate schools. If the different systems show systematic differences in their spending levels, then effectiveness is only one side of efficiency (note, though, that the reported results condition on several measures of resource inputs). It would also be interesting to analyze whether the effect of PPPs differs for students from different parts in the performance distribution, i.e. whether the effects are heterogeneous between elite and disadvantaged students. Specifications that interact the public-private measures with family-background measures could also provide evidence on equity aspects of private involvement. It also remains an open issue whether and how PPPs affect the non-cognitive skills, behaviors and beliefs of students.

Another road for future research would be to look at the different channels through which the effects of PPPs may come about. For example, PPPs may differ from other schools in the education level of the teachers that they hire or in the autonomy that they are granted in different areas, and one may get glimpses of the importance of these different channels by comparing the presented results to regressions that do not control for these other aspects of educational production. Finally, countries differ in the extent to which they impose government restrictions on private schools, and such regulation may limit the extent to which PPPs are allowed to differ from public schools. 


\section{References}

Adams, Ray, Margaret Wu, eds. (2002). PISA 2000 Technical Report. Paris: Organisation for Economic Co-operation and Development (OECD).

Angrist, Joshua, Eric Bettinger, Erik Bloom, Elizabeth King, Michael Kremer (2002). Vouchers for Private Schooling in Colombia: Evidence from a Randomized Natural Experiment. American Economic Review 92 (5): 1535-1558.

Bedi, Arjun S., Ashish Garg (2000). The Effectiveness of Private Versus Public Schools: The Case of Indonesia. Journal of Development Economics 61 (2): 463-494.

Bishop, John H. (1992). The Impact of Academic Competencies on Wages, Unemployment, and Job Performance. Carnegie-Rochester Conference Series on Public Policy 37: 127194.

Bishop, John H., Ludger Wößmann (2004). Institutional Effects in a Simple Model of Educational Production. Education Economics 12 (1): 17-38.

Bradley, Steve, Jim Taylor (2002). The Effect of the Quasi-Market on the Efficiency-Equity Trade-off in the Secondary School Sector. Bulletin of Economic Research 54 (3): 295-314.

Chubb, John E., Terry M. Moe (1990). Politics, Markets, and America's Schools. Washington, D.C.: Brookings Institution Press.

Cox, Donald, Emmanuel Jimenez (1991). The Relative Effectiveness of Private and Public Schools. Journal of Development Economics 34 (1): 99-121.

Deaton, Angus (1997). The Analysis of Household Surveys: A Microeconometric Approach to Development Policy. Baltimore: The Johns Hopkins University Press.

DuMouchel, William H., Greg J. Duncan (1983). Using Sample Survey Weights in Multiple Regression Analyses of Stratified Samples. Journal of the American Statistical Association 78 (383): 535-543.

Epple, Dennis, Richard E. Romano (1998). Competition Between Private and Public Schools, Vouchers, and Peer-Group Effects. American Economic Review 88 (1): 33-62.

Fuchs, Thomas, Ludger Wößmann (2004). What Accounts for International Differences in Student Performance? A Re-examination using PISA Data. CESifo Working Paper 1235. Munich: CESifo.

Galor, Oded, Joseph Zeira (1993). Income Distribution and Macroeconomics. Review of Economic Studies 60 (1): 35-52.

Glomm, Gerhard, B. Ravikumar (1992). Public versus Private Investment in Human Capital: Endogenous Growth and Income Inequality. Journal of Political Economy 100 (4): 818834.

Gradstein, Mark, Moshe Justman (2002). Education, Social Cohesion, and Economic Growth. American Economic Review 92 (4): 1192-1204.

Gradstein, Mark, Moshe Justman, Volker Meier (2004). The Political Economy of Education: Implications for Growth and Inequality. Cambridge, MA: MIT Press.

Greene, William H. (2000). Econometric Analysis. Fourth edition. Upper Saddle River, NJ: Prentice Hall. 
Hanushek, Eric A., with others (1994). Making Schools Work: Improving Performance and Controlling Costs. Washington, D.C.: Brookings Institution Press.

Howell, William G., Patrick J. Wolf, David E. Campbell, Paul E. Peterson (2002). School Vouchers and Academic Performance: Results from Three Randomized Field Trials. Journal of Policy Analysis and Management 21 (2): 191-217.

Hoxby, Caroline M., ed. (2003a). The Economics of School Choice. A National Bureau of Economic Research Conference Report. Chicago: University of Chicago Press.

Hoxby, Caroline M. (2003b). School Choice and School Competition: Evidence from the United States. Swedish Economic Policy Review 10 (3): 9-65.

Hsieh, Chang-Tai, Miguel Urquiola (2003). When Schools Compete, How Do They Compete? An Assessment of Chile's Nationwide School Voucher Program. NBER Working Paper 10008. Cambridge, MA: National Bureau of Economic Research.

Human Development Network (2001). Handbook on Public Private Partnerships in Education. Washington, D.C.: World Bank. (http://www.ifc.org/ifcext/edinvest.nsf/Content/PublicPrivatePartnerships)

James, Estelle, Elizabeth M. King, Ace Suryadi (1996). Finance, Management, and Costs of Public and Private Schools in Indonesia. Economics of Education Review 15 (4): 387-398.

Jimenez, Emmanuel, Vicente Paqueo (1996). Do Local Contributions Affect the Efficiency of Public Primary Schools? Economics of Education Review 15 (4): 377-386.

Ladd, Helen F. (2002). School Vouchers: A Critical View. Journal of Economic Perspectives $16(4): 3-24$.

Levacić, Rosalind (2004). Competition and the Performance of English Secondary Schools: Further Evidence. Education Economics 12 (2): 177-193.

Loury, Glenn C. (1981). Intergenerational Transfers and the Distribution of Earnings. Econometrica 49 (4): 843-867.

Mizala, Alejandra, Pilar Romaguera (2000). School Performance and Choice: The Chilean Experience. Journal of Human Resources 35 (2): 392-417.

Mizala, Alejandra, Pilar Romaguera, Darío Farren (2002). The Technical Efficiency of Schools in Chile. Applied Economics 34 (12): 1533-1552.

Moulton, Brent R. (1986). Random Group Effects and the Precision of Regression Estimates. Journal of Econometrics 32 (3): 385-397.

Neal, Derek (1997). The Effects of Catholic Secondary Schooling on Secondary Achievement. Journal of Labor Economics 15 (1): 98-123.

Nechyba, Thomas J. (2000). Mobility, Targeting, and Private-School Vouchers. American Economic Review 90 (1): 130-146.

Organisation for Economic Co-operation and Development (OECD) (2001). Knowledge and Skills for Life: First Results from the OECD Programme for International Student Assessment (PISA) 2000. Paris: OECD.

Patrinos, Harry A. (2000). Market Forces in Education. European Journal of Education 35 (1): 61-80. 
Patrinos, Harry A. (2002). Private Education Provision and Public Finance: The Netherlands as a Possible Model. NCSPE Occasional Paper No. 59. New York, NY: National Center for the Study of Privatization in Education, Teachers College, Columbia University.

Peterson, Paul E., ed. (2003). The Future of School Choice. Stanford, CA: Hoover Institution Press.

Pritchett, Lant (2003). "When Will They Ever Learn"? Why All Governments Produce Schooling. Bread Working Paper 31. Cambridge, MA: Harvard University, Bureau of Research in Economic Analysis of Development.

Sandström, F. Mikael, Fredrik Bergström (2005). School Vouchers in Practice: Competition Will Not Hurt You. Journal of Public Economics 89 (2-3): 351-380.

Sapelli, Claudio, Bernardita Vial (2002). The Performance of Private and Public Schools in the Chilean Voucher System. Cuadernos de Economía - Latin American Journal of Economics 39 (118): 423-454.

Shleifer, Andrei (1998). State versus Private Ownership. Journal of Economic Perspectives 12 (4): 133-150.

Toma, Eugenia F. (1996). Public Funding and Private Schooling across Countries. Journal of Law and Economics 39 (1): 121-148.

Toma, Eugenia F. (2005). Private Schools in a Global World: 2004 Presidential Address. Southern Economic Journal 71 (4): 693-704.

Vandenberghe, Vincent, Stephane Robin (2004). Evaluating the Effectiveness of Private Education across Countries: A Comparison of Methods. Labour Economics 11 (4): 487506.

Vegas, Emiliana (2002). School Choice, Student Performance, and Teacher and School Characteristics: The Chilean Case. World Bank Policy Research Working Paper 2833. Washington, D.C.: World Bank.

White, Halbert (1984). Asymptotic Theory for Econometricians. Orlando: Academic Press.

Wooldridge, Jeffrey M. (2001). Asymptotic Properties of Weighted M-Estimators for Standard Stratified Samples. Econometric Theory 17 (2): 451-470.

World Bank (2004). World Development Report 2004: Making Services Work for Poor People. Washington, D.C.: World Bank.

Wößmann, Ludger (2001). Why Students in Some Countries Do Better: International Evidence on the Importance of Education Policy. Education Matters 1 (2): 67-74.

Wößmann, Ludger (2003). Schooling Resources, Educational Institutions and Student Performance: the International Evidence. Oxford Bulletin of Economics and Statistics 65 (2): 117-170. 


\section{CESifo Working Paper Series}

(for full list see www.cesifo-group.de)

1601 Jan K. Brueckner, Fiscal Federalism and Economic Growth, November 2005

1602 Steven Brakman, Harry Garretsen and Charles van Marrewijk, Cross-Border Mergers and Acquisitions: On Revealed Comparative Advantage and Merger Waves, November 2005

1603 Erkki Koskela and Rune Stenbacka, Product Market Competition, Profit Sharing and Equilibrium Unemployment, November 2005

1604 Lutz Hendricks, How Important is Discount Rate Heterogeneity for Wealth Inequality?, November 2005

1605 Kathleen M. Day and Stanley L. Winer, Policy-induced Internal Migration: An Empirical Investigation of the Canadian Case, November 2005

1606 Paul De Grauwe and Cláudia Costa Storti, Is Monetary Policy in the Eurozone less Effective than in the US?, November 2005

1607 Per Engström and Bertil Holmlund, Worker Absenteeism in Search Equilibrium, November 2005

1608 Daniele Checchi and Cecilia García-Peñalosa, Labour Market Institutions and the Personal Distribution of Income in the OECD, November 2005

1609 Kai A. Konrad and Wolfgang Leininger, The Generalized Stackelberg Equilibrium of the All-Pay Auction with Complete Information, November 2005

1610 Monika Buetler and Federica Teppa, Should you Take a Lump-Sum or Annuitize? Results from Swiss Pension Funds, November 2005

1611 Alexander W. Cappelen, Astri D. Hole, Erik Ø. Sørensen and Bertil Tungodden, The Pluralism of Fairness Ideals: An Experimental Approach, December 2005

1612 Jack Mintz and Alfons J. Weichenrieder, Taxation and the Financial Structure of German Outbound FDI, December 2005

1613 Rosanne Altshuler and Harry Grubert, The Three Parties in the Race to the Bottom: Host Governments, Home Governments and Multinational Companies, December 2005

1614 Chi-Yung (Eric) Ng and John Whalley, Visas and Work Permits: Possible Global Negotiating Initiatives, December 2005

1615 Jon H. Fiva, New Evidence on Fiscal Decentralization and the Size of Government, December 2005 
1616 Andzelika Lorentowicz, Dalia Marin and Alexander Raubold, Is Human Capital Losing from Outsourcing? Evidence for Austria and Poland, December 2005

1617 Aleksander Berentsen, Gabriele Camera and Christopher Waller, Money, Credit and Banking, December 2005

1618 Egil Matsen, Tommy Sveen and Ragnar Torvik, Savers, Spenders and Fiscal Policy in a Small Open Economy, December 2005

1619 Laszlo Goerke and Markus Pannenberg, Severance Pay and the Shadow of the Law: Evidence for West Germany, December 2005

1620 Michael Hoel, Concerns for Equity and the Optimal Co-Payments for Publicly Provided Health Care, December 2005

1621 Edward Castronova, On the Research Value of Large Games: Natural Experiments in Norrath and Camelot, December 2005

1622 Annette Alstadsæter, Ann-Sofie Kolm and Birthe Larsen, Tax Effects, Search Unemployment, and the Choice of Educational Type, December 2005

1623 Vesa Kanniainen, Seppo Kari and Jouko Ylä-Liedenpohja, Nordic Dual Income Taxation of Entrepreneurs, December 2005

1624 Lars-Erik Borge and Linn Renée Naper, Efficiency Potential and Efficiency Variation in Norwegian Lower Secondary Schools, December 2005

1625 Sam Bucovetsky and Andreas Haufler, Tax Competition when Firms Choose their Organizational Form: Should Tax Loopholes for Multinationals be Closed?, December 2005

1626 Silke Uebelmesser, To go or not to go: Emigration from Germany, December 2005

1627 Geir Haakon Bjertnæs, Income Taxation, Tuition Subsidies, and Choice of Occupation: Implications for Production Efficiency, December 2005

1628 Justina A. V. Fischer, Do Institutions of Direct Democracy Tame the Leviathan? Swiss Evidence on the Structure of Expenditure for Public Education, December 2005

1629 Torberg Falch and Bjarne Strøm, Wage Bargaining and Political Strength in the Public Sector, December 2005

1630 Hartmut Egger, Peter Egger, Josef Falkinger and Volker Grossmann, International Capital Market Integration, Educational Choice and Economic Growth, December 2005

1631 Alexander Haupt, The Evolution of Public Spending on Higher Education in a Democracy, December 2005

1632 Alessandro Cigno, The Political Economy of Intergenerational Cooperation, December 2005 
1633 Michiel Evers, Ruud A. de Mooij and Daniel J. van Vuuren, What Explains the Variation in Estimates of Labour Supply Elasticities?, December 2005

1634 Matthias Wrede, Health Values, Preference Inconsistency, and Insurance Demand, December 2005

1635 Hans Jarle Kind, Marko Koethenbuerger and Guttorm Schjelderup, Do Consumers Buy Less of a Taxed Good?, December 2005

1636 Michael McBride and Stergios Skaperdas, Explaining Conflict in Low-Income Countries: Incomplete Contracting in the Shadow of the Future, December 2005

1637 Alfons J. Weichenrieder and Oliver Busch, Artificial Time Inconsistency as a Remedy for the Race to the Bottom, December 2005

1638 Aleksander Berentsen and Christopher Waller, Optimal Stabilization Policy with Flexible Prices, December 2005

1639 Panu Poutvaara and Mikael Priks, Violent Groups and Police Tactics: Should Tear Gas Make Crime Preventers Cry?, December 2005

1640 Yin-Wong Cheung and Kon S. Lai, A Reappraisal of the Border Effect on Relative Price Volatility, January 2006

1641 Stefan Bach, Giacomo Corneo and Viktor Steiner, Top Incomes and Top Taxes in Germany, January 2006

1642 Johann K. Brunner and Susanne Pech, Optimum Taxation of Life Annuities, January 2006

1643 Naércio Aquino Menezes Filho, Marc-Andreas Muendler and Garey Ramey, The Structure of Worker Compensation in Brazil, with a Comparison to France and the United States, January 2006

1644 Konstantinos Angelopoulos, Apostolis Philippopoulos and Vanghelis Vassilatos, RentSeeking Competition from State Coffers: A Calibrated DSGE Model of the Euro Area, January 2006

1645 Burkhard Heer and Bernd Suessmuth, The Savings-Inflation Puzzle, January 2006

1646 J. Stephen Ferris, Soo-Bin Park and Stanley L. Winer, Political Competition and Convergence to Fundamentals: With Application to the Political Business Cycle and the Size of Government, January 2006

$1647 \mathrm{Yu}-\mathrm{Fu}$ Chen, Michael Funke and Kadri Männasoo, Extracting Leading Indicators of Bank Fragility from Market Prices - Estonia Focus, January 2006

1648 Panu Poutvaara, On Human Capital Formation with Exit Options: Comment and New Results, January 2006 
1649 Anders Forslund, Nils Gottfries and Andreas Westermark, Real and Nominal Wage Adjustment in Open Economies, January 2006

1650 M. Hashem Pesaran, Davide Pettenuzzo and Allan G. Timmermann, Learning, Structural Instability and Present Value Calculations, January 2006

1651 Markku Lanne and Helmut Luetkepohl, Structural Vector Autoregressions with Nonnormal Residuals, January 2006

1652 Helge Berger, Jakob de Haan and Jan-Egbert Sturm, Does Money Matter in the ECB Strategy? New Evidence Based on ECB Communication, January 2006

1653 Axel Dreher and Friedrich Schneider, Corruption and the Shadow Economy: An Empirical Analysis, January 2006

1654 Stefan Brandauer and Florian Englmaier, A Model of Strategic Delegation in Contests between Groups, January 2006

1655 Jan Zápal and Ondřej Schneider, What are their Words Worth? Political Plans and Economic Pains of Fiscal Consolidations in New EU Member States, January 2006

1656 Thiess Buettner, Sebastian Hauptmeier and Robert Schwager, Efficient Revenue Sharing and Upper Level Governments: Theory and Application to Germany, January 2006

1657 Daniel Haile, Abdolkarim Sadrieh and Harrie A. A. Verbon, Cross-Racial Envy and Underinvestment in South Africa, February 2006

1658 Frode Meland and Odd Rune Straume, Outsourcing in Contests, February 2006

1659 M. Hashem Pesaran and Ron Smith, Macroeconometric Modelling with a Global Perspective, February 2006

1660 Alexander F. Wagner and Friedrich Schneider, Satisfaction with Democracy and the Environment in Western Europe - a Panel Analysis, February 2006

1661 Ben J. Heijdra and Jenny E. Ligthart, Fiscal Policy, Monopolistic Competition, and Finite Lives, February 2006

1662 Ludger Woessmann, Public-Private Partnership and Schooling Outcomes across Countries, February 2006 